\title{
IMPLEMENTATION OF DIFFERENTIATED QUALITY MANAGEMENT SYSTEM AND FMEA METHOD IN THE NEWSPAPER PRODUCTION
}

\author{
Jakov Borković, Diana Milčić, Davor Donevski
}

Original scientific paper

A new approach to the FMEA (Failure Mode and Effects Analysis - analysis of potential failures and their effects) method implementation in the newspaper production system shows non-compliances that may occur in the selected processes by implementing differentiated quality management system. Each sub-process and work activity within the selected processes in the newspaper production is differentially evaluated, and analysis provides the necessary information about the intensity of occurrence, severity and possible corrective actions in order to achieve and maintain high levels of quality newspaper products. FMEA analysis is presented in the modified tables for the newspaper product production process, and the preventive and corrective actions were recommended based on the results obtained. By performing preventive and corrective actions the occurrence of non-compliance is eliminated or minimized which ultimately makes the process more competitive and removes the non-compliance from the product.

Keywords: differentiation of quality management systems; FMEA; newspaper production; non-compliance

Implementacija diferenciranog sustava upravljanja kvalitetom i FMEA metode u novinsku proizvodnju

Izvorni znanstveni rad

Novim pristupom u implementaciji FMEA metode u sustavu novinske proizvodnje predstavljene su nesukladnosti koje se mogu pojaviti u odabranim procesima, temeljem primjene diferenciranog sustava upravljanja kvalitetom. Svaki potproces i radna aktivnost u okviru odabranih procesa novinske proizvodnje diferencirano se evaluira, a analizom se dolazi do potrebne informacije o intenzitetu pojavljivanja, serioznosti i mogućim korektivnim mjerama u svrhu postizanja i održanja visoke razine kvalitete novinskog proizvoda. FMEA analiza je predstavljena u modificiranim tabličnim obrascima za proces proizvodnje novinskog proizvoda, a temeljem dobivenih rezultata su preporučene preventivne i korektive aktivnosti. Izvedbom preventivnih i korektivnih aktivnosti, uklanja se ili minimizira pojavljivanje nesukladnosti što u konačnici proces čini konkurentnim i otklanja nesukladnosti iz proizvoda.

Ključne riječi: diferencijacija sustava upravljanja kvalitetom; FMEA; novinska proizvodnja; nesukladnost

\section{Introduction}

Competition and increasing the efficiency have a direct impact on the newspaper industry and investment and search for possible improvements in the production process are necessary to increase profitability. Instead of exclusive care for the improvement in technology, it has become necessary to implement a business model that puts accent on the process performance. Quality management methods have proved to be the options for increasing efficiency of the process. Competition and costs in the printing industry have been steadily increasing, and the increase in profit, which is the goal of any production, can only be achieved by reducing costs and finding and eliminating non-compliance in the production process [1]. The application of tools and methods of quality management systems contributes to meeting requirements of the newspaper production for maximum product quality levels. Since the noncompliance in the production process leads to failures and the cause of non-compliance is not always immediately visible and recognizable, the method of failure analysis and their effects or the FMEA method is appropriate to find the cause of these variations. The causes of certain problems are unknown and it is necessary to conduct scientific researches to explore them. Probable noncompliance, its effects and identification of the cause are basic and initial characteristics of this method. The advantage of the implementation of method of failure mode and effects analysis in the production is more and more obvious, and this paper points to its purpose. The newspaper production is conditioned and defined by customer requirements and wishes therefore the application of this method contributes to customer satisfaction and product quality.

FMEA method can be implemented in systems with quality management system that do not meet the quality requirements defined by the standard [2]. Orientation to the prevention of all potential failures and elimination and reduction of their effects to the lowest possible level makes this method different in comparison to similar methods. The applicability of the method is reflected in its simplicity and adaptability to all views of a problem. However, there are certain sectors of economy with more frequent application of this method [3]. There is a general procedure for the FMEA method implementation, however specific details vary depending on the standards of organizations or activities [4]. Following the decision on the team selection for the FMEA method implementation, it is of utmost importance to determine the scope of the FMEA analysis. The quality management differentiation precedes the application of the FMEA in order to avoid unnecessary quality costs. It is recommended to use a flow diagram to determine the scope and ensure the participation of each member of the team responsible for the FMEA implementation [5].

\section{Implementation of the quality management system differentiation}

Implementation of the quality management system differentiation in the newspaper printing house is appropriate for the systems which have already implemented one of the well-known quality management systems. From a total of five newspaper printing houses investigated, only one has not implemented the ISO 
quality management system (QFS). This approach to quality management enables the printing process of a certain newspaper product to be observed in its organizational and technological complexity.
Implementation of vertical differentiation in a simplified form, i.e. degree of complexity in the NP system is shown in Tab. 1.

Table 1 Degree of complexity in the newspaper production system

\begin{tabular}{|c|c|c|c|c|c|c|c|c|c|c|c|c|c|c|c|c|c|c|}
\hline PROCESSES & \multicolumn{5}{|c|}{$\begin{array}{l}\text { ORGANISATIONAL } \\
\text { COMPLEXITY }\end{array}$} & \multicolumn{5}{|c|}{$\begin{array}{l}\text { TECHNOLOGICAL } \\
\text { COMPLEXITY }\end{array}$} & \multicolumn{5}{|c|}{$\begin{array}{c}\text { QUALITY } \\
\text { REQUIREMENTS }\end{array}$} & \multicolumn{3}{|c|}{$\begin{array}{l}\text { DEGREE OF } \\
\text { COMPLEXITY }\end{array}$} \\
\hline PRINTING HOUSES & I & II & III & IV & $\mathrm{V}$ & I & II & III & IV & $\mathrm{V}$ & I & II & III & IV & $\mathrm{V}$ & $\Sigma$ & $\varnothing$ & RANG \\
\hline Purchase department & 2 & 2 & 1 & 2 & 2 & 1 & 1 & 2 & 1 & 1 & 3 & 3 & 3 & 3 & 3 & 28 & 1,8 & II \\
\hline Sales department & 2 & 3 & 2 & 2 & 2 & 1 & 1 & 1 & 2 & 1 & 3 & 3 & 2 & 2 & 3 & 30 & 2 & II \\
\hline Stock & 2 & 2 & 1 & 2 & 2 & 2 & 2 & 2 & 2 & 3 & 2 & 1 & 2 & 2 & 3 & 31 & 2,1 & II \\
\hline Maintenance & 2 & 2 & 2 & 2 & 2 & 2 & 3 & 2 & 2 & 3 & 3 & 3 & 2 & 3 & 3 & 36 & 2,4 & II \\
\hline Prepress & 3 & 3 & 3 & 2 & 3 & 3 & 3 & 3 & 3 & 3 & 2 & 3 & 3 & 3 & 2 & 42 & 2,8 & I \\
\hline Offset plates production & 2 & 3 & 3 & 3 & 3 & 3 & 3 & 3 & 3 & 3 & 3 & 3 & 3 & 2 & 3 & 43 & 2,9 & I \\
\hline Preprint & 3 & 3 & 2 & 3 & 3 & 3 & 3 & 3 & 3 & 3 & 3 & 3 & 3 & 3 & 2 & 43 & 2,9 & I \\
\hline Print & 3 & 3 & 3 & 2 & 3 & 3 & 3 & 3 & 3 & 3 & 3 & 3 & 3 & 3 & 3 & 44 & 2,9 & $\mathrm{I}$ \\
\hline Newspaper product finishing & 3 & 2 & 3 & 2 & 1 & 2 & 3 & 1 & 2 & 3 & 3 & 2 & 2 & 1 & 3 & 33 & 2,2 & II \\
\hline Newspaper dispatch & 2 & 3 & 2 & 3 & 3 & 3 & 3 & 2 & 3 & 3 & 2 & 3 & 3 & 2 & 3 & 40 & 2,67 & I \\
\hline Planning and analysis & 2 & 1 & 2 & 1 & 2 & 1 & 1 & 1 & 1 & 2 & 2 & 1 & 1 & 2 & 1 & 21 & 1,4 & III \\
\hline Finance & 3 & 2 & 2 & 2 & 1 & 1 & 1 & 1 & 1 & 3 & 2 & 2 & 2 & 2 & 2 & 27 & 1,8 & II \\
\hline Controlling & 1 & 2 & 2 & 1 & 1 & 1 & 1 & 1 & 1 & 1 & 1 & 2 & 2 & 2 & 2 & 21 & 1,4 & III \\
\hline Bookkeeping and Accounting & 2 & 2 & 2 & 1 & 2 & 1 & 1 & 1 & 1 & 1 & 2 & 2 & 2 & 2 & 2 & 22 & 1,5 & III \\
\hline $\begin{array}{l}\text { Administration and Human } \\
\text { Resources }\end{array}$ & 1 & 2 & 1 & 1 & 1 & 1 & 1 & 1 & 1 & 1 & 1 & 1 & 2 & 2 & 1 & 18 & 1,2 & III \\
\hline Quality management & 2 & 2 & 2 & 3 & 2 & 2 & 3 & 2 & 2 & 1 & 3 & 2 & 2 & 2 & 2 & 32 & 2,1 & II \\
\hline Waste management & 1 & 1 & 2 & 1 & 1 & 1 & 1 & 1 & 1 & 2 & 1 & 2 & 1 & 2 & 2 & 20 & 1,3 & III \\
\hline
\end{tabular}

In Tab. 1 the quality requirements are expressed as: high with grade 3 , medium with grade 2 and low with grade 1 . The value of the total degree of complexity is expressed as the sum score of organizational and technological complexity and the quality requirements. The degree of complexity for the observed processes was rated in the following way: category I average score for total degree of complexity ranges from 2,5 to 3 , from 1,5 to 2,5 in category II and from 1 to 1,5 in category III.

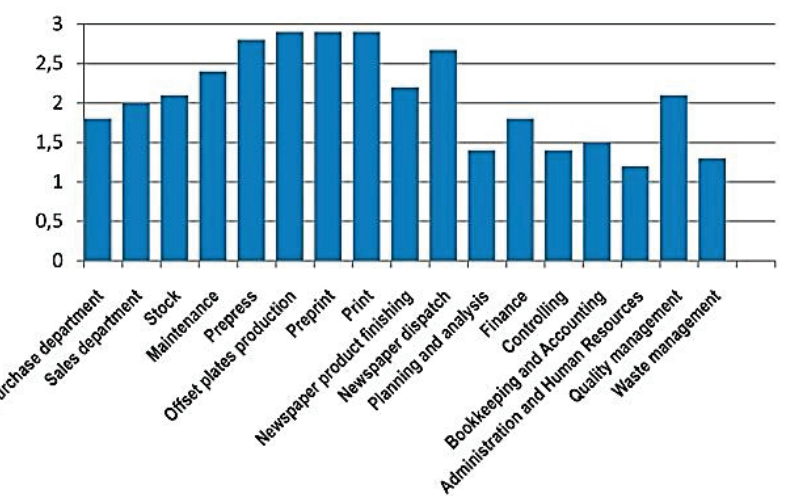

Figure 1Degree of complexity of the newspaper production process

Tab. 1 shows that vertical differentiation conditioned by the organizational and technological complexity also represents the starting point for the quality management differentiation in the organization of the newspaper production. The survey on organizational and technological complexity and quality requirements was conducted in five newspaper printing houses marked in the study's I, II, III, IV and V.

In accordance with the quality requirements and a high degree of complexity, the focus of quality management system will be on the processes of high organizational and technological complexity. Due to the effects of QMS implementation, the processes of medium and low technological complexity and quality requirements are expected to be marginalized. In any case, a detailed review of Tab. 1 and histogram in Fig. 1 show that the processes of Preprint and Print have the highest degree of complexity, as well as Graphic prepress, Offset plate production and Newspaper dispatch. This is rather an expected order, and it will be used in further research, analysis and application of the FMEA methodology.

\section{Implementation of the FMEA methodology}

Planning, quality assurance and control in the newspaper production system are implemented after the quality management system differentiation and identification of the newspaper production processes with the highest level of technological and organizational complexity and quality requirements.

With respect to the processes, sub-processes and tasks, the tools and techniques of quality management system were selected to detect reasons for the time unnecessary spent in the newspaper production processes and suggest certain corrections to avoid them. All influencing parameters occurring in the newspaper production processes were systematically investigated to determine the areas that are the cause of non-compliance (effects) [6].

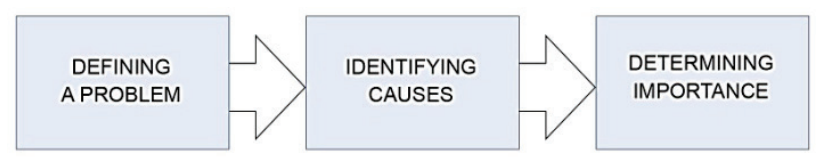

Figure 2 Phases in identifying the causes, effect size and leaders of the corrective actions 
The process of identifying causes, effect size and leaders of the corrective actions was implemented in three stages according to Fig. 2.

With regard to the problem characteristics, a modified FMEA table was applied as a tool of the quality management system suitable for the implementation of measures for potential improvement. The process of implementation of the FMEA is the use of tools, i.e. analytical method which considers possible causes of non-compliance regarding time, products or production processes and possible ways of their elimination $[7,8]$. This method may identify potential non-compliance within the production process or the product itself, simulate the effect of non-compliance to the end user, identify potential non-compliance in the production and point to the places that need to be controlled in order to reduce and eliminate non-compliance. This method may help to draw up a list of potential non-compliance and develop a method of corrective and preventive measures for their control. The FMEA-tables, not standardized and varying depending on the goals of the analysis, are used for this purpose [9]. The entire production process is systematically analysed by this method in order to determine all possible causes of non-compliance. The production process needs to be divided analytically in the sub-processes and all functions of these components need to be determined. This phase of the FMEA-table implementation provides the basic information offered by this method. Based on the reliability assessment grades gained by analysing the newspaper production, the modifications in the processes are carried out in order to avoid possible non-compliance. This procedure is performed by filling the field in the table which calculates the risk priority number (RPN - Risk Priority Number) according to the degree of severity of non-compliance (SEV - Severity), the occurrence of non-compliance (OCC - Occurrence) and the detection of non-compliance (DET - Detection). Assessment of the degree of severity of non-compliance in the process can be viewed from several angles and evaluated numerically from 1 to 10 (1 for no or minimal effects to 10 for drastic effects threatening the system itself). The occurrence of noncompliance in the OCC field is the information necessary for selecting the components to be improved and it results from the nature of the cause of non-compliance. It is also evaluated numerically, from 1 for a very small probability of non-compliance to 10 for an almost certain occurrence of non-compliance. Detection of non-compliance is also evaluated on a scale from 1 for almost certain detection of non-compliance to 10 for absolute improbability for detection of non-compliance [10].

\section{Research and results: creating a modified FMEA table}

The modified FMEA-table was used to determine the RPN and obtain its relevant values. The sequence of creating the FMEA consists of defining the production process, identifying possible time lag and evaluating possible effects of non-compliance due to time lag in the newspaper production process. An overall criticality $(S)$ is assigned by taking these influential parameters into account. Possible causes, their character and noncompliance are identified and their strength $(O)$ is assessed. Then the implemented supervision of the workprocesses analysed and probability of detection of non-compliance is assessed by applying current methods of supervision and control $(D)$.

The risk priority number is calculated using the formula: $R P N=O \times S \times D$.

In the analysed example the RNP values greater than 100 are considered significant, those ranging from 10 to 100 are less significant, and below 10 insignificant. If the greater RPN value is in question, the component of noncompliance is more complex and should get higher priority when making modifications to the production system [11].

\subsection{FMEA implementation in the graphic prepress}

Next step, upon completion of the analysis and evaluation, is taking corrective actions. The sequence, from the recommendations for implementation of corrective actions to evaluation of the results of the implemented activities, is displayed in the FMEA form created by implementing the following steps in the graphic prepress.

The first part of FMEA form, Tab. 2, shows that RPN values in all seven sub-processes are greater than 100, indicating a demand for the implementation of certain corrective measures. Corrections are based on the results obtained from the cause and effect diagram.

The experiment or corrective actions that can be seen in the second part of FMEA form started upon completing the analysis and evaluation, Tab. 3. The sequence, from the recommendations for implementation of corrective actions to evaluation of the results of the implemented activities is displayed in the second part of the FMEA form by the following steps:

I. Recommended corrective actions were implemented. They were in particular associated with improvements in the sub-process of receiving and control of the product elements by developing precise instructions for receiving and control of materials and development of procedures; in the next sub-process - graphic design and development of the product layout - there was no archive with key parameters related to customers (mainly in relation to the advertisements in the newspaper), so the layout and archive with key parameters were created. All sub-processes within graphic prepress process were accessed in the same way according to the identified critical points or areas for improvement.

II. Leaders of corrective action implementation were selected; it means that responsible employees were appointed according to their function in the process of corrective action implementation.

III. A detailed analysis of the implemented activities was performed.

IV. Assessment and analysis of the achieved results were repeated. 
Table 2 Adapted FMEA form for the process graphic prepress I part

\begin{tabular}{|c|c|c|c|c|c|c|}
\hline PRODUCTION PROCESSES & TIME LAG EFFECT & SEV & TIME LAG CAUSE & OCC & DET & RPN \\
\hline $\begin{array}{l}\text { Receiving and control of the } \\
\text { product elements }\end{array}$ & $\begin{array}{l}\text { Prolonged period of reviewing } \\
\text { received pages }\end{array}$ & 6 & $\begin{array}{l}\text { No standardized procedure in } \\
\text { receiving the materials }\end{array}$ & 6 & 5 & 180 \\
\hline $\begin{array}{l}\text { Graphic design and product } \\
\text { layout creation }\end{array}$ & $\begin{array}{l}\text { Useless search for layout } \\
\text { elements and production of } \\
\text { creations previously done }\end{array}$ & 4 & $\begin{array}{l}\text { No archive with key parameters } \\
\text { related to the customers and the } \\
\text { basic product forms }\end{array}$ & 7 & 6 & 168 \\
\hline $\begin{array}{l}\text { Image processing, retouching, } \\
\text { and digitizing }\end{array}$ & $\begin{array}{l}\text { Processing and pre-determination } \\
\text { of the size of all images } \\
\text { regardless of page break }\end{array}$ & 3 & $\begin{array}{l}\text { No standardized procedure for } \\
\text { selection, processing and } \\
\text { formatting of images }\end{array}$ & 6 & 7 & 126 \\
\hline Assembly & $\begin{array}{l}\text { Use less waiting for certain } \\
\text { elements for graphical layout } \\
\text { completion }\end{array}$ & 5 & $\begin{array}{l}\text { Due to delay in client's choosing } \\
\text { the materials }\end{array}$ & 5 & 7 & 175 \\
\hline $\begin{array}{l}\text { Computer processing and } \\
\text { assembly }\end{array}$ & $\begin{array}{l}\text { Incomplete control of the } \\
\text { technological distribution by the } \\
\text { operator in assembly }\end{array}$ & 6 & $\begin{array}{l}\text { No direct contact between } \\
\text { technologists and operators in the } \\
\text { computers assembly }\end{array}$ & 4 & 7 & 168 \\
\hline Sending to CtP platesetter & $\begin{array}{l}\text { Possibility of the faster montage } \\
\text { output to the platesetter device }\end{array}$ & 4 & $\begin{array}{l}\text { Separate montage output to } \\
\text { lighting by the plate arrangement }\end{array}$ & 6 & 5 & 120 \\
\hline
\end{tabular}

Table 3 Adapted FMEA form for the process graphic prepress II part

\begin{tabular}{|c|c|c|c|c|c|c|c|}
\hline $\begin{array}{l}\text { PRODUCTION } \\
\text { PROCESSES }\end{array}$ & $\begin{array}{c}\text { RECOMMENDED } \\
\text { CORRECTIVE ACTIONS }\end{array}$ & RESPONSIBILITIES & $\begin{array}{c}\text { IMPLEMENTED } \\
\text { CORRECTIVE ACTIONS }\end{array}$ & SEV & $\mathrm{OCC}$ & DET & PRPN \\
\hline $\begin{array}{l}\text { Receiving and control of } \\
\text { the product elements }\end{array}$ & $\begin{array}{l}\text { Create correct guidelines } \\
\text { for receiving the material }\end{array}$ & Operator & $\begin{array}{l}\text { Implemented } \\
\text { standardized procedure } \\
\text { in receiving the materials }\end{array}$ & 5 & 3 & 5 & 75 \\
\hline $\begin{array}{l}\text { Graphic design and } \\
\text { product layout creation }\end{array}$ & $\begin{array}{l}\text { Creating unified layout } \\
\text { and archive with key } \\
\text { parameters related to the } \\
\text { customers }\end{array}$ & Operator & $\begin{array}{l}\text { Creating an archive with } \\
\text { unified layouts }\end{array}$ & 3 & 4 & 5 & 60 \\
\hline $\begin{array}{l}\text { Image processing, } \\
\text { retouching, and } \\
\text { digitizing }\end{array}$ & $\begin{array}{l}\text { Create the accurate } \\
\text { guidelines for selection, } \\
\text { processing and } \\
\text { formatting of images }\end{array}$ & Operator & $\begin{array}{l}\text { Implemented accurate } \\
\text { guidelines for selection, } \\
\text { processing and } \\
\text { formatting of images }\end{array}$ & 3 & 5 & 6 & 90 \\
\hline Assembly & $\begin{array}{l}\text { Define the priority level } \\
\text { in page break creation }\end{array}$ & Operator & $\begin{array}{l}\text { Defined priority level in } \\
\text { page break creation }\end{array}$ & 4 & 4 & 5 & 80 \\
\hline $\begin{array}{l}\text { Computer processing } \\
\text { and assembly }\end{array}$ & $\begin{array}{l}\text { Create a procedure in the } \\
\text { control and distribution } \\
\text { of computer assembly }\end{array}$ & Operator & $\begin{array}{l}\text { Created the procedure on } \\
\text { the control of computer } \\
\text { assembly }\end{array}$ & 5 & 3 & 5 & 75 \\
\hline $\begin{array}{l}\text { Sending to CtP } \\
\text { platesetter }\end{array}$ & $\begin{array}{l}\text { Defining the way of } \\
\text { montage output to } \\
\text { lighting }\end{array}$ & Operator & $\begin{array}{l}\text { Defined the way of } \\
\text { montage output to } \\
\text { lighting }\end{array}$ & 3 & 3 & 4 & 36 \\
\hline
\end{tabular}

Table 4 Adapted FMEA form for offset plate process I part

\begin{tabular}{|c|c|c|c|c|c|c|}
\hline PRODUCTION PROCESSES & TIME LAG EFFECT & SEV & TIME LAG CAUSE & $\mathrm{OCC}$ & DET & RPN \\
\hline $\begin{array}{l}\text { Receiving database of digital } \\
\text { pages }\end{array}$ & $\begin{array}{l}\text { Long period of monitoring and } \\
\text { control of the received database }\end{array}$ & 6 & $\begin{array}{l}\text { Organisation and technical } \\
\text { equipment for monitoring } \\
\text { database }\end{array}$ & 7 & 5 & 210 \\
\hline Exposure of the offset plates & $\begin{array}{l}\text { Prepress present when exposing } \\
\text { the offset plates }\end{array}$ & 5 & $\begin{array}{l}\text { Individual offset plate insertion is } \\
\text { not implemented }\end{array}$ & 6 & 4 & 120 \\
\hline Offset plate finishing & $\begin{array}{l}\text { Time loss in rearrangement of the } \\
\text { offset plates in distribution by } \\
\text { cylinders of the rotating machine }\end{array}$ & 5 & $\begin{array}{l}\text { Punched finished plates are not } \\
\text { arranged to fit distribution by } \\
\text { cylinders of the rotating machine }\end{array}$ & 5 & 5 & 125 \\
\hline Control of the offset plates & $\begin{array}{l}\text { Unnecessary controls are carried } \\
\text { out in the whole work - flow }\end{array}$ & 4 & $\begin{array}{l}\text { Measurements of the control } \\
\text { fields on the plates are performed } \\
\text { regardless of the life span of the } \\
\text { developer }\end{array}$ & 6 & 5 & 120 \\
\hline $\begin{array}{l}\text { Delivery of offset plates to the } \\
\text { printing house }\end{array}$ & $\begin{array}{l}\text { Slow delivery of offset plates to } \\
\text { the printing house }\end{array}$ & 7 & $\begin{array}{l}\text { Unnecessary loss of time in } \\
\text { offset plates transport }\end{array}$ & 6 & 4 & 165 \\
\hline
\end{tabular}

\subsection{FMEA implementation in the offset plate production}

In this process the corrective actions are performed upon completion of the analysis and assessment as well. All activities, from recommendations for the corrective action implementation to the evaluation of the results of the implemented activities, are displayed in the FMEA form created by implementing the following steps in the process of offset plate production.
After analysing the first part of the FMEA form, Tab. 4 , regarding causes and consequences of the occurrence of non-compliance in the process of offset plate production, it can be concluded that RPN values for all six sub-processes are greater than 100 , which leads to demand for corrective action implementation. Recommended corrective actions can be seen in the second part of the FMEA form, Tab. 5, and actual improvements happen in the sub-process of offset plate processing. The perforated finished plates do not fold in 
order to correspond to distribution by the offset machine cylinders. The implemented corrective action is the transport route adjustment from CtP device to the presscutter for faster plate distribution. In the next process of the file control there was no time lag, so there were no proposals for the process improvement. In further subprocesses the recommended corrective actions were carried out in accordance with identified causes and consequences as seen in the form. Furthermore, leaders of corrective actions implementation were selected, i.e. the responsible employee in the process of corrective action implementation was appointed. Next step was analysing the activities undertaken and the repeated evaluation and analysis of the results obtained.

Table 5 Adapted FMEA form for offset plate process II part

\begin{tabular}{|c|c|c|c|c|c|c|c|}
\hline $\begin{array}{l}\text { PRODUCTION } \\
\text { PROCESSES }\end{array}$ & $\begin{array}{c}\text { RECOMMENDED } \\
\text { CORRECTIVE ACTIONS }\end{array}$ & RESPONSABILITIES & $\begin{array}{c}\text { IMPLEMENTED } \\
\text { CORRECTIVE ACTIONS }\end{array}$ & SEV & OCC & DET & PRPN \\
\hline $\begin{array}{l}\text { Receiving database of } \\
\text { digital pages }\end{array}$ & $\begin{array}{l}\text { Organizing monitoring } \\
\text { of the received database } \\
\text { on several displays at the } \\
\text { same time }\end{array}$ & Operator & $\begin{array}{l}\text { Organized monitoring of } \\
\text { database as } \\
\text { recommended }\end{array}$ & 4 & 5 & 4 & 80 \\
\hline $\begin{array}{l}\text { Exposure of the offset } \\
\text { plates }\end{array}$ & $\begin{array}{l}\text { Eliminate prepress } \\
\text { organisationally when } \\
\text { exposing the offset plates }\end{array}$ & Operator & $\begin{array}{l}\text { Prepress eliminated, } \\
\text { plates inserted } \\
\text { individually } \\
\end{array}$ & 4 & 5 & 3 & 60 \\
\hline Offset plate finishing & $\begin{array}{l}\text { Extend the transport } \\
\text { route from the exposure } \\
\text { to the punching machine } \\
\text { for the faster } \\
\text { redistribution of plates }\end{array}$ & Operator & $\begin{array}{l}\text { Transport route extended } \\
\text { for faster redistribution } \\
\text { of preformation flow }\end{array}$ & 4 & 3 & 4 & 48 \\
\hline $\begin{array}{l}\text { Control of the offset } \\
\text { plates }\end{array}$ & $\begin{array}{l}\text { Controls are carried out } \\
\text { when changing } \\
\text { developer of different } \\
\text { manufacturer even out of } \\
\text { time of the process }\end{array}$ & Operator & $\begin{array}{l}\text { Standardised offset plate } \\
\text { control process }\end{array}$ & 3 & 5 & 4 & 60 \\
\hline $\begin{array}{l}\text { Delivery of offset plates } \\
\text { to the printing house }\end{array}$ & $\begin{array}{l}\text { It is proposed to use } \\
\text { several transport carts } \\
\text { designated for each } \\
\text { group of cylinders }\end{array}$ & Operator & $\begin{array}{l}\text { Transport carts with } \\
\text { barriers are used to } \\
\text { project several linked } \\
\text { cylinders }\end{array}$ & 5 & 3 & 3 & 75 \\
\hline
\end{tabular}

Table 6 Adapted FMEA form for the preprint stage of production I part

\begin{tabular}{|c|c|c|c|c|c|c|}
\hline PRODUCTION PROCESSES & TIME LAG EFFECT & SEV & TIME LAG CAUSE & $\mathrm{OCC}$ & DET & RPN \\
\hline Preprint & $\begin{array}{l}\text { Wasting time on sorting } \\
\text { productions (launching a new } \\
\text { product) }\end{array}$ & 5 & $\begin{array}{l}\text { Productions are not always } \\
\text { arranged by product name and } \\
\text { technical parameters }\end{array}$ & 6 & 5 & 150 \\
\hline $\begin{array}{l}\text { Preparing paper on the rotating } \\
\text { machine }\end{array}$ & $\begin{array}{l}\text { Time of arranging rolls in the } \\
\text { facility, longer time needed for } \\
\text { installing paper roll on the } \\
\text { carrier, longer time till the first } \\
\text { correct impression }\end{array}$ & 6 & $\begin{array}{l}\text { Depending on the number of } \\
\text { newspaper pages, they may be } \\
\text { printed on rolls of different } \\
\text { widths and spend more time }\end{array}$ & 6 & 4 & 144 \\
\hline $\begin{array}{l}\text { Preparing ink on the rotating } \\
\text { machine }\end{array}$ & $\begin{array}{l}\text { Due to unconditioned ink } \\
\text { (temperature) there is a time loss } \\
\text { during preparation for starting } \\
\text { print }\end{array}$ & 7 & $\begin{array}{l}\text { Standardized amount for each set } \\
\text { of ink in the containers is not } \\
\text { prepared on time }\end{array}$ & 5 & 6 & 210 \\
\hline $\begin{array}{l}\text { Preparation of paper folding } \\
\text { machine }\end{array}$ & $\begin{array}{l}\text { During the preparation of the } \\
\text { paper folding machine there is no } \\
\text { possibility for immediate } \\
\text { reaching the } 60 \% \text { maximum } \\
\text { speed }\end{array}$ & 5 & $\begin{array}{l}\text { Punctures on the foldable } \\
\text { cylinder need to be changed } \\
\text { before they are completely worn } \\
\text { out }\end{array}$ & 5 & 6 & 150 \\
\hline
\end{tabular}

\subsection{FMEA implementation in the preprint stage of production}

The corrective actions in the preprint stage of production were performed after completing the analysis and evaluation. All activities, from recommendations for the corrective action implementation to the evaluation of the results of the implemented activities, are displayed on the FMEA form created by implementing the following steps in the preprint stage of production.

Based on the time lag effects, its identified causes, the recommended corrective actions were performed due to the fact that the first part of the FMEA form in Tab. 6 shows that RPN values in all five sub-processes were greater than 100, indicating the demand for corrective actions starting from sub-process of production preparation in which productions were not sorted by product and technical parameters.

Recommended corrective actions are completed. In further sub-processes, the recommended corrective actions were carried out in accordance with identified causes and effects, as seen in the second part of the FMEA form, Tab. 7. The leaders of implementation in certain sub-processes in which corrective actions were taken, i.e. the responsible employees were appointed. Next step was analysing the activities undertaken and the repeated evaluation and analysis of the results obtained. 
Table 7 Adapted FMEA form for the preprint stage of production II part

\begin{tabular}{|c|c|c|c|c|c|c|c|}
\hline $\begin{array}{l}\text { PRODUCTION } \\
\text { PROCESSES } \\
\end{array}$ & $\begin{array}{c}\text { RECOMMENDED } \\
\text { CORRECTIVE ACTIONS }\end{array}$ & RESPONSIBILITIES & $\begin{array}{c}\text { IMPLEMENTED } \\
\text { CORRECTIVE ACTIONS }\end{array}$ & SEV & $\mathrm{OCC}$ & DET & PRPN \\
\hline Preprint & $\begin{array}{l}\text { Sort productions by the } \\
\text { product name and basic } \\
\text { technical parameters }\end{array}$ & Operator & $\begin{array}{l}\text { Productions sorted by } \\
\text { the product name and } \\
\text { basic technical } \\
\text { parameters }\end{array}$ & 4 & 5 & 4 & 80 \\
\hline $\begin{array}{l}\text { Preparing paper on the } \\
\text { rotating machine }\end{array}$ & $\begin{array}{l}\text { Make proper selection of } \\
\text { rolls, prepare reports on } \\
\text { the stock status on time }\end{array}$ & Operator & $\begin{array}{l}\text { Adjusted technological } \\
\text { solutions according to } \\
\text { the stock status }\end{array}$ & 5 & 4 & 3 & 60 \\
\hline $\begin{array}{l}\text { Preparing ink on the } \\
\text { rotating machine }\end{array}$ & $\begin{array}{l}\text { Refuel the machine } \\
\text { containers for prepress } \\
\text { jobs on time }\end{array}$ & Operator & $\begin{array}{l}\text { Procedure for preparing } \\
\text { inks on the machine } \\
\text { completed }\end{array}$ & 5 & 3 & 5 & 75 \\
\hline $\begin{array}{l}\text { Preparation of paper } \\
\text { folding machine }\end{array}$ & $\begin{array}{l}\text { Order the operator to } \\
\text { change the puncture } \\
\text { according to the } \\
\text { specified schedule }\end{array}$ & Operator & $\begin{array}{l}\text { Procedure for changing } \\
\text { punctures completed }\end{array}$ & 4 & 4 & 5 & 80 \\
\hline
\end{tabular}

Table 8 Adapted FMEA form for the printing process I part

\begin{tabular}{|c|c|c|c|c|c|c|}
\hline PRODUCTION PROCESSES & TIME LAG EFFECT & SEV & TIME LAG CAUSE & OCC & DET & RPN \\
\hline \multirow{2}{*}{$\begin{array}{l}\text { START OF THE PRINTING } \\
\text { PROCESS } \\
\text { 1. Time needed to reach } \\
\text { equilibrium }\end{array}$} & $\begin{array}{l}\text { Time needed to reach } \\
\text { equilibrium is extended }\end{array}$ & 7 & $\begin{array}{l}\text { Settings without minimal ink } \\
\text { layer }\end{array}$ & 6 & 6 & 252 \\
\hline & $\begin{array}{l}\text { Time needed to reach } \\
\text { equilibrium is extended }\end{array}$ & 7 & $\begin{array}{l}\text { No pre-preparation of the water } \\
\text { solution }\end{array}$ & 6 & 5 & 210 \\
\hline \multirow{3}{*}{ 2. Time up for ink application } & $\begin{array}{l}\text { Time up for ink application is } \\
\text { extended }\end{array}$ & 7 & $\begin{array}{l}\text { Surface temperature of the paper } \\
\text { rolls is not examined }\end{array}$ & 5 & 6 & 210 \\
\hline & $\begin{array}{l}\text { Time up for ink application is } \\
\text { extended }\end{array}$ & 7 & $\begin{array}{l}\text { Impression control has not } \\
\text { started on time }\end{array}$ & 5 & 6 & 210 \\
\hline & $\begin{array}{l}\text { Time up for ink application is } \\
\text { extended }\end{array}$ & 7 & $\begin{array}{l}\text { Changing the speed of the } \\
\text { machine by switching to the } \\
\text { "second phase" due to the fine } \\
\text { regulation. }\end{array}$ & 5 & 6 & 210 \\
\hline \multirow{3}{*}{$\begin{array}{l}\text { 3. Time up to the moment of } \\
\text { receiving the first correct } \\
\text { newspapers }\end{array}$} & $\begin{array}{l}\text { Time up to the moment of } \\
\text { receiving the first correct } \\
\text { newspapers is extended }\end{array}$ & 8 & $\begin{array}{l}\text { Simultaneous regulation of strip } \\
\text { cutting, registry and coating is } \\
\text { not taken into account }\end{array}$ & 6 & 6 & 288 \\
\hline & $\begin{array}{l}\text { Time up to the moment of } \\
\text { receiving the first correct } \\
\text { newspapers is extended }\end{array}$ & 8 & $\begin{array}{l}\text { Badly printed copies of } \\
\text { newspapers are not separated } \\
\text { manually when registries are } \\
\text { disrupted }\end{array}$ & 6 & 6 & 288 \\
\hline & $\begin{array}{l}\text { Time up to the moment of } \\
\text { receiving the first correct } \\
\text { newspapers is extended }\end{array}$ & 8 & $\begin{array}{l}\text { The principle of the roll width in } \\
\text { printing to use the whole one } \\
\text { first, then the used one is not } \\
\text { applied }\end{array}$ & 6 & 6 & 288 \\
\hline \multirow{2}{*}{$\begin{array}{l}\text { 4. Time of communication } \\
\text { between foreman of the rotation } \\
\text { and dispatch }\end{array}$} & $\begin{array}{l}\text { Time of communication between } \\
\text { foreman of the rotation and } \\
\text { dispatch is extended } \\
\text { new editions are not included in } \\
\text { the study* }\end{array}$ & 7 & $\begin{array}{l}\text { Upon reaching the equilibrium } \\
\text { the operator does not control the } \\
\text { printed newspaper and does not } \\
\text { separate for editorial board in } \\
\text { the newspaper dispatch }\end{array}$ & 5 & 7 & 245 \\
\hline & $\begin{array}{l}\text { Time of communication between } \\
\text { foreman of the rotation and } \\
\text { dispatch is extended }\end{array}$ & 7 & $\begin{array}{l}\text { The operator does not respond } \\
\text { quickly to disturbed parameters } \\
\text { (registry and application of inks) }\end{array}$ & 5 & 7 & 245 \\
\hline $\begin{array}{l}\text { 5. Control of the printed copies } \\
\text { Press production }\end{array}$ & $\begin{array}{l}\text { Time loss till max. fast regulation } \\
\text { of all parameters during } \\
\text { newspapers printing }\end{array}$ & 7 & $\begin{array}{l}\text { No prepared "database" on } \\
\text { previously known productions } \\
\text { for max. fast regulation of } \\
\text { parameters in printing }\end{array}$ & 6 & 5 & 210 \\
\hline 6. Machine stopping & $\begin{array}{l}\text { Printing time wasted on printing } \\
\text { to complete circulation when } \\
\text { numerator stops counting } \\
\text { circulation }\end{array}$ & 7 & $\begin{array}{l}\text { Within the machine stopping } \\
\text { time correct copies are still } \\
\text { printed or approximately } 5 \mathrm{~s}\end{array}$ & 6 & 6 & 252 \\
\hline
\end{tabular}

\subsection{FMEA implementation in the printing process}

The corrective actions in the printing process were performed after completing the analysis and evaluation. Recommendations for the corrective action implementation, evaluation of the results of the implemented activities, and responsibilities of employees are displayed on the FMEA form created by implementing the following steps in the printing process. 


\begin{tabular}{|c|c|c|c|c|c|c|c|}
\hline $\begin{array}{l}\text { PRODUCTION } \\
\text { PROCESSES } \\
\end{array}$ & \begin{tabular}{|c|} 
RECOMMENDED \\
CORRECTIVE ACTIONS \\
\end{tabular} & RESPONSIBILITIES & $\begin{array}{c}\text { IMPLEMENTED } \\
\text { CORRECTIVE ACTIONS } \\
\end{array}$ & SEV & OCC & DET & PRPN \\
\hline \multirow{2}{*}{$\begin{array}{l}\text { START PRINTING } \\
\text { PROCESS } \\
\text { 1. Time needed to reach } \\
\text { equilibrium }\end{array}$} & $\begin{array}{l}\text { Set settings with minimal } \\
\text { application of ink }\end{array}$ & Operator & $\begin{array}{l}\text { Settings with minimal } \\
\text { application of ink are set }\end{array}$ & 5 & 4 & 3 & 60 \\
\hline & $\begin{array}{l}\text { Preparation of the water } \\
\text { solution } 15 \text { minutes } \\
\text { before printing, add } \\
\text { another } 1 \% \text { of puffer } \\
\end{array}$ & Operator & $\begin{array}{l}\text { Water solution pre- } \\
\text { prepared on time and } \\
\text { added } 1 \%\end{array}$ & 5 & 4 & 4 & 80 \\
\hline \multirow{3}{*}{$\begin{array}{l}\text { 2. Time up for ink } \\
\text { application }\end{array}$} & $\begin{array}{l}\text { Check that the surface } \\
\text { temperature of the paper } \\
\text { does not deviate more } \\
\text { than } 5 \% \text { at the edges and } \\
\text { in the centre of the paper } \\
\text { rolls }\end{array}$ & Operator & $\begin{array}{l}\text { Surface temperature of } \\
\text { the paper rolls is checked }\end{array}$ & 6 & 4 & 4 & 96 \\
\hline & $\begin{array}{l}\begin{array}{l}\text { Examine pages at the } \\
\text { edge of the roll and } \\
\text { prepare a zone }\end{array} \\
\end{array}$ & Operator & $\begin{array}{l}\text { Pages at the edge of the } \\
\text { roll are examined, zone } \\
\text { is prepared at } \\
\text { approximately } 10 \%\end{array}$ & 5 & 4 & 4 & 80 \\
\hline & $\begin{array}{l}\text { Do not change the speed } \\
\text { of the machine by } \\
\text { switching to the second } \\
\text { phase }\end{array}$ & Operator & $\begin{array}{l}\text { Switching to the second } \\
\text { phase was performed } \\
\text { without changing the } \\
\text { speed of the machine }\end{array}$ & 5 & 3 & 4 & 60 \\
\hline \multirow{3}{*}{$\begin{array}{l}\text { 3. Time up to the } \\
\text { moment of receiving the } \\
\text { first correct newspapers }\end{array}$} & \begin{tabular}{|l|} 
Upon reaching the \\
equilibrium regulate at \\
the same time strip \\
cutting, registry and \\
application of ink at both \\
control panels \\
\end{tabular} & Operator & $\begin{array}{l}\text { Simultaneous regulation } \\
\text { of strip cutting, registry } \\
\text { and application of ink is } \\
\text { done }\end{array}$ & 6 & 4 & 5 & 120 \\
\hline & $\begin{array}{l}\text { When registers in the } \\
\text { printing process disrupt } \\
\text { it is necessary to keep } \\
\text { the speed, and extract } \\
\text { bad copies of } \\
\text { newspapers in dispatch }\end{array}$ & Operator & $\begin{array}{l}\text { Machine speed is kept in } \\
\text { the phase of establishing } \\
\text { the working speed, bad } \\
\text { copies are extracted in } \\
\text { dispatch }\end{array}$ & 6 & 3 & 5 & 90 \\
\hline & $\begin{array}{l}\text { Avoid putting less than } \\
\text { half of the roll to start } \\
\text { printing }\end{array}$ & Operator & $\begin{array}{l}\text { Implement the principle } \\
\text { of printing first with the } \\
\text { whole roll than with the } \\
\text { used one }\end{array}$ & 5 & 4 & 4 & 64 \\
\hline \multirow{2}{*}{$\begin{array}{l}\text { 4. Time of } \\
\text { communication between } \\
\text { foreman of the rotation } \\
\text { and dispatch }\end{array}$} & $\begin{array}{l}\text { Upon reaching } \\
\text { equilibrium it is } \\
\text { recommended that the } \\
\text { dispatch operator } \\
\text { controls the newspapers } \\
\text { printed before extraction }\end{array}$ & Operator & $\begin{array}{l}\text { Dispatch operator } \\
\text { performed control and } \\
\text { extraction of the } \\
\text { newspapers }\end{array}$ & 6 & 5 & 4 & 100 \\
\hline & $\begin{array}{l}\text { The operator must not } \\
\text { interrupt the printing } \\
\text { process. They must react } \\
\text { quickly }\end{array}$ & Operator & $\begin{array}{l}\text { Implemented } \\
\text { recommendation on } \\
\text { keeping the speed of } \\
\text { printing in case of } \\
\text { disturbed parameters } \\
\text { with quick intervention } \\
\end{array}$ & 5 & 5 & 5 & 100 \\
\hline $\begin{array}{l}\text { 5. Control of the printed } \\
\text { copies } \\
\text { Press production }\end{array}$ & $\begin{array}{l}\text { The foreman should } \\
\text { identify the production, } \\
\text { defines its name and } \\
\text { regulates the printing by } \\
\text { parameters known in } \\
\text { advance } \\
\end{array}$ & Operator & $\begin{array}{l}\text { Database of previously } \\
\text { known productions for } \\
\text { regulating printing } \\
\text { parameters was } \\
\text { constructed }\end{array}$ & 5 & 3 & 4 & 60 \\
\hline 6. Machine stopping & \begin{tabular}{|l|} 
Correct printed copies \\
after printing completion \\
should be included in \\
total circulation
\end{tabular} & Operator & $\begin{array}{l}\text { Printing was completed } \\
\text { after printing planned } \\
\text { number of correct } \\
\text { printed newspapers }\end{array}$ & 5 & 3 & 4 & 100 \\
\hline
\end{tabular}

Since the printing process is a demanding phase in the newspaper production, the sub-process "start of the printing process's" divided into: time needed to reach equilibrium, time up to minimal ink layer, time up to the moment of receiving the first correct newspapers copy is extended and time of communication between foreman of the rotation and dispatch. In each of these phases the full range of time lag effects was detected as seen in the first part of the FMEA form, Tab. 8. The recommended corrective actions relating to time lag in the sub-process "start of the printing process" in prolonging the time needed to reach equilibrium are caused by settings not set to the minimal ink layer. The effect of prolonged time for applying enough ink is caused by not measuring surface 
temperature of the paper rolls. In all successive subprocesses the recommended corrective actions were carried out in accordance with the identified causes and effects, as seen in the FMEA form, Tab. 9. These corrective measures were carried out by the carriers of implementation, i.e. responsible employees were appointed in the process of corrective action implementation.

Next step was analysing the activities undertaken and repeated evaluation and analysis of the results obtained.

Table 10 Adapted FMEA form for the newspaper dispatch process I part

\begin{tabular}{|c|c|c|c|c|c|c|}
\hline PRODUCTION PROCESSES & TIME LAG EFFECT & SEV & TIME LAG CAUSE & $\mathrm{OCC}$ & DET & RPN \\
\hline Preparation of the stacker & $\begin{array}{l}\text { Unnecessary management of a } \\
\text { large number of packages }\end{array}$ & 6 & $\begin{array}{l}\text { Maximum packet size }(8 \mathrm{~kg}) \text { is } \\
\text { not used }\end{array}$ & 5 & 4 & 120 \\
\hline Taking newspapers from rotation & $\begin{array}{l}\text { Time loss in taking newspapers } \\
\text { from rotation }\end{array}$ & 6 & $\begin{array}{l}\text { Counters are exclusively used in } \\
\text { taking newspapers }\end{array}$ & 6 & 5 & 180 \\
\hline $\begin{array}{l}\text { Newspapers are disposed on the } \\
\text { pallets }\end{array}$ & $\begin{array}{l}\text { Time loss due to the complaints } \\
\text { about the number of newspapers } \\
\text { in packages when re-packaging }\end{array}$ & 7 & $\begin{array}{l}\text { Inadequate control of the number } \\
\text { of newspapers in packages }\end{array}$ & 5 & 5 & 175 \\
\hline Disposal of pallet & $\begin{array}{l}\text { Time loss while looking for and } \\
\text { manipulating the pallets for the } \\
\text { next production process }\end{array}$ & 7 & $\begin{array}{l}\text { Pallets with printed newspapers } \\
\text { are not stacked by the ongoing } \\
\text { process of finishing }\end{array}$ & 5 & 4 & 140 \\
\hline Sorting and gluing addresses & $\begin{array}{l}\text { Creating additional phases of } \\
\text { work and additional expenditure } \\
\text { of time }\end{array}$ & 6 & $\begin{array}{l}\text { The addresses is placed after } \\
\text { removing papers from the pallet }\end{array}$ & 6 & 4 & 144 \\
\hline Loading of vehicles & $\begin{array}{l}\text { Time loss due to the transport of } \\
\text { the finished packages (hand and } \\
\text { machine-made) in the transport } \\
\text { vehicle }\end{array}$ & 7 & $\begin{array}{l}\text { All packages of newspapers with } \\
\text { addresses are sent to the vehicle } \\
\text { via conveyor belt }\end{array}$ & 6 & 4 & 168 \\
\hline
\end{tabular}

Table 11 Adapted FMEA form for the newspaper dispatch process II part

\begin{tabular}{|c|c|c|c|c|c|c|c|}
\hline $\begin{array}{l}\text { PRODUCTION } \\
\text { PROCESSES } \\
\end{array}$ & $\begin{array}{c}\text { RECOMMENDED } \\
\text { CORRECTIVE ACTIONS } \\
\end{array}$ & RESPONSABILITIES & $\begin{array}{c}\text { IMPLEMENTED } \\
\text { CORRECTIVE ACTIONS } \\
\end{array}$ & SEV & $\mathrm{OCC}$ & DET & PRPN \\
\hline $\begin{array}{l}\text { Preparation of the } \\
\text { stacker }\end{array}$ & $\begin{array}{l}\text { Implementation of the } \\
\text { maximum packet size in } \\
\text { the newspapers packages } \\
\text { management }\end{array}$ & Operator & $\begin{array}{l}\text { Implemented procedure } \\
\text { for managing the } \\
\text { maximum packet size }\end{array}$ & 5 & 4 & 2 & 40 \\
\hline $\begin{array}{l}\text { Taking newspapers from } \\
\text { rotation }\end{array}$ & $\begin{array}{l}\text { Monitoring a set of } \\
\text { parameters that ensure } \\
\text { the smooth taking } \\
\text { newspapers from rotation } \\
\text { besides the counter usage }\end{array}$ & Operator & $\begin{array}{l}\text { Issued order for } \\
\text { monitoring the whole } \\
\text { range of parameters for } \\
\text { taking newspapers }\end{array}$ & 4 & 5 & 4 & 80 \\
\hline $\begin{array}{l}\text { Newspapers are disposed } \\
\text { on the pallets }\end{array}$ & $\begin{array}{l}\text { Recommendation to use } \\
\text { a digital scale and weigh } \\
\text { randomly selected } \\
\text { packages of newspapers }\end{array}$ & Operator & $\begin{array}{l}\text { Using a digital scale } \\
\text { when controlling the } \\
\text { number of newspapers in } \\
\text { the packages }\end{array}$ & 5 & 4 & 3 & 60 \\
\hline Disposal of pallet & $\begin{array}{l}\text { Recommendation to } \\
\text { deposit pallets of } \\
\text { newspapers by priority } \\
\text { of the following working } \\
\text { operation }\end{array}$ & Operator & $\begin{array}{l}\text { Implemented procedure } \\
\text { on the deposit of the } \\
\text { pallets with printed } \\
\text { newspapers }\end{array}$ & 5 & 4 & 3 & 60 \\
\hline $\begin{array}{l}\text { Sorting and gluing } \\
\text { addresses }\end{array}$ & $\begin{array}{l}\text { Place full packages on } \\
\text { the prepared place on the } \\
\text { tables instead of the } \\
\text { pallets }\end{array}$ & Operator & $\begin{array}{l}\text { Implemented procedure } \\
\text { on the flow of packages } \\
\text { of newspapers being } \\
\text { addressed }\end{array}$ & 4 & 3 & 4 & 48 \\
\hline Loading of vehicles & $\begin{array}{l}\text { Deliver addressed hand- } \\
\text { made packages to the } \\
\text { vehicle by hand, not via } \\
\text { conveyor belt }\end{array}$ & Operator & $\begin{array}{l}\text { Implemented procedure } \\
\text { for loading addressed } \\
\text { packages of newspapers } \\
\text { to the vehicle }\end{array}$ & 5 & 3 & 4 & 60 \\
\hline
\end{tabular}

In assessing the results after implemented activities in the second part of the FMEA form, Tab. 9, it can be seen that production phase of time up to applying enough ink reaches the RPN of 96, the RPN of the production phase of time up to receive the first copy of the newspapers is 120 , and the time of communication between foreman of the rotation and dispatch revealed two cases noncompliance is 100. It is obvious that there is still room for implementing new corrective actions, but since it is about a small time savings, the need and effectiveness of further implementation is under consideration.

\subsection{FMEA implementation in the newspaper dispatch process}

In the newspaper dispatch process the corrective actions were performed after completing the analysis and evaluation, shown in Tab. 10. All activities, from recommendations for the corrective action implementation to the evaluation of the results of the implemented activities, are displayed on the FMEA form created by implementing the following steps in the process of dispatch. 
Recommended corrective actions are related to the improvements in the sub process of preparing the stacker by making maximum packet size in the newspapers packaging due to unnecessary handling of a large number of packages, which saves time. And in a further subprocess, as seen in the FMEA form, Tab. 11, the recommended corrective actions were made in accordance with identified causes and effects. The leaders of the corrective actions implementation in certain subprocesses, i.e. the responsible employees were appointed. Next step was analysing the implemented activities and the repeated evaluation and analysis of the results obtained.

\section{Conclusion}

Control of the production processes is important, especially in the newspaper production, and the methods for controlling the process quality as well. Based on the results of this study it can be concluded that there are noncompliances which extend the time of the newspaper production in certain phases ultimately leading to the price increase and the lack of competitiveness. Besides quality, the price of graphic products is one of the crucial parameters for surviving in competitive markets. Therefore, the quality control, by including all influential parameters and not just the production time, cannot be left to chance or the assumption that a competent and quality newspaper product will be made in an optimal time frame meeting the customer requirements. It takes a systematic approach to improve the quality of the newspaper product and production process using methods of quality management system that will reduce the incidence of time lag and ultimately remove it from the newspaper production system. This paper confirmed the usability of the FMEA method in the newspaper production.

\section{References}

[1] Samuelson, P. A.; Nordhaus, W. D. Ekonomija, Mate izdanja, Zagreb, 2013.

[2] URL: www.juran.com (06.08.2015)

[3] Lazibat, T. Upravljanje kvalitetom, Znanstvena knjiga d.o.o., Zagreb, 2009.

[4] Deming, W. E. The new Economics, The MIT Press, Cambridge, 2000.

[5] Drljača, M. Troškovi kvalitete - povijesni razvoj spoznaja I perspektive, Zagreb: Hrvatsko društvo menadžera kvalitete. // Zbornik radova 5. Simpozija: Suvremena stremljenja u upravljanju kvalitetom. (2003), pp. 151-159

[6] Tomaš, A. Optimizacija odabranih parametara u sustavu novinskog offset tiska. // Magistarski rad, Grafički fakultet Sveučilišta u Zagrebu, Zagreb, 2011.

[7] Bakć, I.; Krizmanić, K. Primjena FMEA metode kontrole kvalitete u grafičkoj industriji. // 15. Međunarodna konferencija tiskarstva, dizajna i grafičkih komunikacija, Senj: Ogranak Matice Hrvatske u Senju, Grafički fakultet Sveučilišta u Zagrebu, 2011.

[8] Dobrović, T.; Tadić, D.; Stanko, Z. FMEA metoda u upravljanju kvalitetom, Zagreb: Poslovna izvrsnost, 2008. URL: hrcak.srce.hr/file/60579, (16.09.2015)

[9] Droždek, I. Analiza rizika i njihovih utjecaja, FMEA (Failure Mode and Effects Analysis). // Tehnički glasnik. 8, 1(2014), pp. 25-33.
[10] Stamatis, D. H. Failure Mode and Effects Analysis: FMEA from Theory to Execution, American Society for Quality Press, Milwaukee, 2003.

[11] McDermott, E. R.; Mikulak, J. R.; Beaurgard, R. M. The basic of FMEA, Productivity Inc., New York. 1996.

\section{Authors' addresses}

Jakov Borković, dipl. ing. graf.

Alterpress d.o.o.

Lička 33, 10000 Zagreb, Croatia

E-mail: jakov.borkovic@gmail.com

prof. dr. sc. Diana Milčić, dipl. ing. stroj.

University of Zagreb Faculty of Graphic Arts Getaldićeva 2, 10000 Zagreb, Croatia

E-mail:dmilcic@grf.hr

dr. sc. Davor Donevski, dipl. ing. graf. University of Zagreb Faculty of Graphic Arts Getaldićeva 2, 10000 Zagreb, Croatia

E-mail: davor.donevski@grf.hr 